\title{
BULLYING ENTRE MENINAS E O DESAFIO DA CONSTRUÇÃO DE RESILIÊNCIA NA ESCOLA
}

\section{BULLYING AMONG GIRLS AND THE CHALLENGE OF BUILDING RESILIENCE AT SCHOOL}

\author{
Flávia Maria dos Santos Vasconcelos ${ }^{1}$ \\ Universidade Estadual de Campinas (UNICAMP), SP, Brasil \\ Hugo Monteiro Ferreira ${ }^{2}$ \\ Universidade Federal Rural de Pernambuco, PE, Brasil
}

\begin{abstract}
Resumo: Este trabalho intenta analisar e discutir os processos de empoderamento e resiliência de meninas alvo de bullying na escola. $\mathrm{O}$ recorte de gênero se faz essencial à medida que ainda há pouco material que contemple as particularidades do bullying entre meninas. A pesquisa empírica aconteceu numa Escola de Referência em Ensino Médio (EREM), na cidade do Recife, no ano de 2017. Ela foi dividida em duas etapas: a primeira contou com a participação de 91 meninas matriculadas nas três séries do ensino médio e aconteceu a partir da aplicação de um Questionário sobre a temática; para a segunda etapa, foram selecionadas 45 meninas que participaram de Rodas de Diálogo na intenção de discutir os eixos centrais desta pesquisa. Por meio da análise dos dados coletados, entende-se que o fortalecimento de meninas vítimas de bullying, através do empoderamento de seus traços identitários, pode fomentar o desenvolvimento de resilência e se tornar um caminho possível para o enfrentamento da questão.
\end{abstract}

Palavras-chave: Bullying, Empoderamento, Resiliência, Gênero, Escola

\begin{abstract}
This work aims to analyze and discuss the processes of empowerment and resilience of girls who are the target of bullying at school. The gender focus is essential as there is still little material that addresses the particularities of bullying among girls. The empirical research took place at a High School Reference School (EREM), in the city of Recife, in the year 2017. It was divided into two stages: the first had the participation of 91 girls enrolled in the three grades of high school and it took place from the application of a Questionnaire on the theme; for the second stage, 45 girls were selected who participated in Dialog Wheels in order to discuss the central axes of this research. Through the analysis of the collected data, it is understood that the strengthening of girls who are victims of bullying, through the empowerment of their identity traits, can foster the development of resilience and become a possible way to face the issue.
\end{abstract}

Keywords: Bullying, Empowerment, Resilience, Gender, School

\section{INTRODUÇÃO}

Alejandra era adolescente quando sua mãe faleceu e precisou mudar de cidade com seu pai para iniciar uma nova etapa de sua vida. Na nova cidade, integrou-se de maneira natural à nova

\footnotetext{
${ }^{1}$ Doutoranda em Sociologia pela Universidade Estadual de Campinas (UNICAMP). E-MAIL: flaviamariastvsc@gmail.com.

${ }^{2}$ Doutor em educação pela Universidade Federal do Rio Grande do Norte (UFRN), Professor Adjunto do Departamento de Educação da UFRPE. E-MAIL: hmonteiroferreira@yahoo.com.br. ORCID: https://orcid.org/00000003-4583-831X

Revista Tópicos Educacionais, Pernambuco, v. 27, n. 01, p.34-61, 2021. ISSN: 2448-0215. https://periodicos.ufpe.br/revistas/topicoseducacionais/index Dossiê "Conflitos, violências, bullying na escola: problemas da convivência potencializado pela pandemia?" DOI: 10.51359/2448-0215.2021.250294
} 


\section{Revista Tópicos Educacionais}

rotina, à escola, aos colegas de classe. Até que um dia, em uma festa, envolveu-se com um dos garotos de sua turma, que filmou o encontro sexual e repassou para outras pessoas. A partir daí, a vida de Alejandra se transformou completamente. Ela foi perseguida, aviltada e abusada física e emocionalmente por todos que considerava seus amigos e, de maneira especial, suas amigas mais próximas.

A conturbada e angustiante história de Alejandra faz parte do enredo do filme Después de Lucia $^{3}$, contudo, possui um caráter universal: poderia ser a história de qualquer adolescente, de qualquer parte do mundo, nos dias atuais. O que Alejandra sofre no filme é uma forma de perseguição específica que ganha, cada dia, mais espaço nas discussões acerca de Direitos Humanos, educação, ambiente e clima escolar: o bullying. Entende-se por bullying o conjunto de práticas violentas (sejam elas de caráter físico, moral, relacional, eletrônico, etc.) que acontecem de forma repetitiva, intencional e sem nenhum motivo aparente, evidenciando uma relação desigual de poder (FANTE, 2005).

O bullying é um fenômeno rico de ramificações e que transpassa barreiras geográficas e de classe, ou seja, pode acontecer em qualquer canto do mundo, sem distinguir ambientes escolares mais abastados dos mais marginalizados. Em 1970, o pesquisador Dan Olweus, professor da Universidade de Bergen, na Noruega, relacionou pela primeira vez a questão da violência escolar específica com o termo bullying. Olweus, estudando as tendências suicidas em adolescentes, descobriu que havia uma relação direta entre a ideação, as tentativas e o suicídio propriamente dito com as situações de violência que esses/as jovens sofriam, como ameaças, maus-tratos e desafetos com seus/suas companheiros/as de escola. Para ele, só é possível que um tipo de violência seja classificado como bullying se estiver implícito uma assimetria de poder entre as duas partes envolvidas (OLWEUS, 1997).

É comum observar crianças e adolescentes sendo ridicularizadas e abusadas por ter alguma limitação física ou cognitiva, por sua cor, etnia, orientação sexual, religião, tipo físico, ou gênero e faz-se importante entender as diferentes formas de violência que o fenômeno pode gerar. $\mathrm{O}$ bullying praticado por e contra meninas, por exemplo, tem um caráter diferenciado, aparecendo majoritariamente sob a forma verbal (tanto na infância quanto na adolescência), que inclui fofocas,

\footnotetext{
${ }^{3}$ DESPUÉS de Lucía. Direção: Michel Franco. Produção de Marco Polo Constandse, Michel Franco et al. Local: México, França. IMOVISION, 2012.

Revista Tópicos Educacionais, Pernambuco, v. 27, n. 01, p.34-61, 2021. ISSN: 2448-0215. https://periodicos.ufpe.br/revistas/topicoseducacionais/index Dossiê "Conflitos, violências, bullying na escola: problemas da convivência potencializado pela pandemia?" DOI: $10.51359 / 2448-0215.2021 .250294$
} 
exclusão do grupo social e apelidos (BANDEIRA; HUTZ, 2012). É sobre esse tipo em particular, o bullying ${ }^{4}$ praticado por e contra meninas, que este trabalho se debruça.

Usualmente, a violência praticada por e contra meninas adolescentes se diferencia pela ação não-física, o que muitas vezes, a faz passar despercebida pelos adultos ao redor da menina alvo/autora. Segundo Leon (2005), ao analisar-se a adolescência a partir do desenvolvimento cognitivo e intelectual, essa se conforma enquanto um período de intensas e profundas mudanças qualitativas na estrutura do pensamento. Além disso, é também neste período da vida que se toma início a formação de um raciocínio social, que "se vincula como conhecimento do $e u$ e os outros, a aquisição das habilidades sociais, o conhecimento e a aceitação/negação dos princípios da ordem social, e com a aquisição e o desenvolvimento moral e de valor dos adolescentes" (LEON, 2005, p. 11). É inegável a importância das experiências nesta fase para a composição do/a sujeito/a ao longo de sua vida.

Dessa forma, torna-se primordial um olhar mais acurado para o ambiente onde, inicialmente, tudo acontece: a escola. Avaliando como se dá a construção do sistema educacional, de maneira disciplinar e fragmentada, centrada no cumprimento de normas duras e no controle dos corpos, gestos e comportamentos (FOUCAULT, 1987, p.199), com pouco ou nenhum diálogo entre educadores e estudantes, percebe-se que há uma falha de base. Nitidamente, essa proposta não mais atende às demandas da sociedade atual, já que desde muito cedo crianças e adolescentes têm acesso a uma quantidade de informação impensada décadas atrás, e assim desenvolvem novos questionamentos e novas maneiras de lidar com o mundo e com sua realidade, expondo a escola enquanto um espaço despreparado para receber essas demandas.

A necessidade de fomentar debates acerca de conteúdos extracurriculares, como o bullying, mostra sua relevância também no desenvolvimento de mecanismos de enfrentamento aos mais diversos problemas. Resiliência é um conceito próprio da física, e nomeia a capacidade que um corpo tem de, ao passar por uma situação de deformação, conseguir se regenerar e voltar a sua

\footnotetext{
${ }^{4}$ É importante pontuar que há hoje discussões no âmbito dos movimentos sociais sobre como bullying pode ser um termo "guarda-chuva" para questões como racismo, machismo, homo/lesbo/transfobia, capacitismo, gordofobia, entre outras formas de preconceito e violência que parte de um grupo socialmente constituído por traços identitários hegemônicos, contra outros que pertença a alguma minoria historicamente oprimida. Assim, na intenção de respeitar este desconforto e acreditando no valor deste como um posicionamento político sobre a temática, nesta pesquisa optou-se por utilizar o termo bullying exclusivamente com pessoas pertencentes à faixa etária escolar regular. Mantem-se este posicionamento também devido ao entendimento de que os indivíduos (crianças e adolescentes) que se encaixam no perfil de alvo/autor/a devem ser tratados de acordo com o que a legislação propõe: de maneira pedagógica, sendo o/a autor/a passível de tratamento e acompanhamento psicopedagógico tanto quanto o alvo.

Revista Tópicos Educacionais, Pernambuco, v. 27, n. 01, p.34-61, 2021. ISSN: 2448-0215. https://periodicos.ufpe.br/revistas/topicoseducacionais/index Dossiê "Conflitos, violências, bullying na escola: problemas da convivência potencializado pela pandemia?" DOI: $10.51359 / 2448-0215.2021 .250294$
} 
forma original. Bastante utilizado na psicologia para demonstrar a aptidão dos indivíduos de atravessar situações estressantes sem entrar em surto, resiliência se apresenta enquanto uma ferramenta de autorregulação interna que todas as pessoas têm, mas algumas desenvolvem de maneira mais eficaz do que outras. É um artifício que, combinado com ações efetivas de instituições - como a escola e a família — para a proteção das crianças e adolescentes, torna-se valoroso no enfrentamento ao bullying.

À vista disso, a discussão aqui realizada pensa o empoderamento de traços identitários como um caminho possível na desconstrução do bullying entre meninas. A mobilização desses dois conceitos conjugados é feita na intenção de articular e pensar coletivamente questões sociais utilizadas como base para o bullying, entendendo que o acolhimento e o fortalecimento das pessoas alvo se conformam enquanto uma prática essencial na tratativa da questão. Assim, o objetivo central deste trabalho é analisar e discutir os processos de empoderamento e resiliência de meninas alvo de bullying na escola.

Para a realizar a discussão aqui apresentada, teve-se como ponto de partida algumas questões primárias: Como se dá o bullying entre meninas? De que forma a escola lida com a violência entre pares? Essas meninas procuram ajuda? Se sim, de quem e como? O que faz uma menina deixar de ser alvo de bullying? De que maneira o bullying afeta a vivência dessas meninas?

Ferreira (2016) entende que a causa matriz do bullying está relacionada à rejeição à diversidade e ao diverso, isto é, rejeita-se aquilo que não é sinônimo e, em razão da rejeição, objetiva-se à eliminação por meio da perseguição sistemática, provocando sofrimento para quem não se adequa ao modelo identitário imposto como referência. Dessa forma, além de olhar para o espaço que propicia essa prática, é preciso também entender quem é "o outro" e de que maneira essas relações se conformam.

Entendendo as disparidades de gênero

Bullying é a violência sistemática direcionada a um alvo por uma pessoa ou por um grupo específico. Muito antes de violência gratuita, quando falamos de bullying, também estamos falando de relações de poder. De maneira geral, meninos costumam demonstrar seu poder através

Revista Tópicos Educacionais, Pernambuco, v. 27, n. 01, p.34-61, 2021. ISSN: 2448-0215. https://periodicos.ufpe.br/revistas/topicoseducacionais/index

Dossiê "Conflitos, violências, bullying na escola: problemas da convivência potencializado pela pandemia?" DOI: 10.51359/2448-0215.2021.250294 
de força física: é a sua imposição corporal que reverbera no seu status, especialmente na infância. Meninas, usualmente, tendem a fundamentar sua popularidade (e, portanto, seu poder) através de mecanismos que não exigem força física, como intrigas e fofocas, buscando um destaque social (BANDEIRA; HUTZ, 2012).

Foucault (1995) coloca que uma relação de violência age de maneira a aniquilar qualquer reação que não a passividade, ainda que encontre resistência, sua tendência é reduzi-la. Já uma relação de poder se conforma a partir do tipo de manipulação que torna o sujeito dominado reconhecido e mantido como o sujeito de ação. Essa dominação baseada no poder se efetiva através do consentimento tácito dado pelo indivíduo que sofre a violência. Agindo a partir da sutileza e/ou do convencimento, toda a resistência que ali nasceria de imediato se dissipa, dando lugar à submissão.

Louro (2010) afirma que a disparidade na maneira de meninos e meninas lidarem com questões de bullying está diretamente relacionada com uma pedagogia dos corpos que lhes é imposta desde a mais tenra idade, especialmente nas escolas. Essa pedagogia dá base à generificação desses corpos que desde os primórdios são educados de maneira bastante diferenciada. Há construções de masculinidade e feminilidade que normatizam e evidenciam de um lado as questões físicas, como jogos, luta, esportes radicais, velocidade, competição, violência; e do outro, questões ligadas à obediência, subserviência, maternidade, delicadeza.

Se tratando da violência entre pares, existem três personagens que podem ser distintos ou misturar seus papeis: o/a autor/ra, o alvo e o/a espectador/ra. $\mathrm{O}$ alvo de bullying costuma ter um perfil mais frágil, dificuldade de socialização, tende a ser tímido e reservado e pouco ou nada reage às provocações. O/a espectador/ra, como o próprio nome diz, é aquele/la que testemunha a agressão, não participando ativamente dela. $\mathrm{O} / \mathrm{a}$ autor/ra mostra-se desde cedo bastante averso/a às regras, não aceita ser contrariado/a e, frequentemente, tem perfil de liderança (SILVA, 2010). Há uma diferença na forma de agressão das crianças e adolescentes meninos, sendo no primeiro caso observado o uso de violência física em maior predominância, já no segundo a violência começa a acontecer de forma mais simbólica, a partir de ameaças, provocações, insultos ou deboches (BANDEIRA, 2009).

Analisando-se o caso das meninas, não se observa essa mudança: seja criança ou adolescente, o bullying praticado por e contra meninas tem um caráter mais verbal, ligado a xingamentos, geralmente colocando em evidência algum traço físico ou identitário, atuando para

Revista Tópicos Educacionais, Pernambuco, v. 27, n. 01, p.34-61, 2021. ISSN: 2448-0215. https://periodicos.ufpe.br/revistas/topicoseducacionais/index Dossiê "Conflitos, violências, bullying na escola: problemas da convivência potencializado pela pandemia?" DOI: $10.51359 / 2448-0215.2021 .250294$ 
evidenciar a exclusão social (MENEGOTTO; PASINI; LEVANDOWSKI, 2013). Os processos de construção de identidades, relacionados aos diferentes papeis sociais distribuídos entre homens e mulheres é a base dessa distinção.

Se por um lado o bullying entre meninos tende a ser minimizado como uma competição natural pela liderança, por outro, o bullying entre meninas costuma ser tratado como "coisa de mulher", naturalizando uma questão que o próprio Movimento Feminista tenta, de forma contundente, problematizar e desconstruir: a rivalidade feminina. Essa rivalidade é retratada como intrínseca às mulheres, algo que sempre existiu em toda sociedade onde há mais de uma mulher e que sempre tomará as formas de uma competição. Esse processo se perpetua como condição para que se mantenha uma ordem social de dominação masculina, estando completamente enraizado na vida das mulheres.

A competição está arraigada e é legitimada nas mais diversas esferas. bell hooks ${ }^{5}$ (2000), feminista negra e acadêmica estadunidense, coloca que

Todas nós sabíamos em primeira mão que tínhamos sido socializadas como mulheres pelo pensamento patriarcal de nos vermos como inferiores aos homens, de nos vermos como sempre e apenas em competição umas com as outras pela aprovação patriarcal, de olhar umas para as outras com ciúme, medo e ódio. O pensamento sexista nos fez julgar umas às outras sem compaixão e punir umas às outras com severidade. O pensamento feminista nos ajudou a desaprender o ódio feminino por nós mesmas. Isso nos permitiu nos libertar do controle que o pensamento patriarcal exercia sobre nossa consciência (HOOKS, 2000, p. 14). ${ }^{6}$

Sororidade é o termo utilizado para designar a fraternidade entre as mulheres. Pode ser definida como uma maneira ética e política de construir laços de irmandade entre as mulheres, “(...)de onde advém práticas que propõe, preservam e estimulam mútua proteção, solidariedade e a defesa de direitos de classe a partir de vivências no contexto patriarcal (PENKALA, 2014, p. 225). Era uma palavra pouco utilizada no Brasil, porém a partir das traduções feitas da literatura

\footnotetext{
${ }^{5} \mathrm{O}$ nome da autora está escrito em letras minúsculas respeitando a tradição que a própria cunhou. Segundo ela "O mais importante em meus livros é a substância e não quem sou eu", rejeitando qualquer magnitude que venha a ter nomes e títulos.

${ }^{6}$ Em livre tradução: That foundation rested on our critique of what we then called "the enemy within," referring to our internalized sexism. We all knew firsthand that we had been socialized as females by patriarchal thinking to see ourselves as inferior to men, to see ourselves as always and only in competition with one another for patriarchal approval, to look upon each other with jealousy, fear, and hatred. Sexist thinking made us judge each other without compassion and punish one another harshly. Feminist thinking helped us unlearn female self-hatred. It enabled us to break free of the hold patriarchal thinking had on our consciousness.

Revista Tópicos Educacionais, Pernambuco, v. 27, n. 01, p.34-61, 2021. ISSN: 2448-0215. https://periodicos.ufpe.br/revistas/topicoseducacionais/index Dossiê "Conflitos, violências, bullying na escola: problemas da convivência potencializado pela pandemia?" DOI: $10.51359 / 2448-0215.2021 .250294$
} 
feminista inglesa, começou a se popularizar dentro do movimento de mulheres, ganhando força especialmente após sua difusão nas redes sociais.

Atualmente a sororidade é vista a partir da dimensão ética, prática e política do feminismo, levando mulheres a repensar suas relações, a partir de uma ótica mais saudável, na intenção de construir uma ordem social mais democrática e que promova a equidade de gêneros, eliminando todas as formas de opressão sobre a mulher. É também “conscientizar as mulheres sobre a misoginia. É um esforço pessoal e coletivo de destruir a mentalidade e a cultura misógina, enquanto transforma as relações de solidariedade entre as mulheres" (GARCIA; SOUSA, 2015, p.1003).

Tal qual hooks (2000) aponta, esse trabalho de criação de vínculo deve se basear também em questões de raça e classe, entendendo que a prática antissexista precisa perpassar a ideia de sucesso a partir de uma lógica de apoio e não-dominação de umas sobre as outras. É essa concepção de sororidade/irmandade, com uma leitura crítica sobre as diferentes condições das diferentes mulheres (raça/etnia, classe, condição física, etc) sobre acolhimento, apoio e fortalecimento dos vínculos, que se soma a outro conceito caro aos movimentos de mulheres e que vem sendo bastante evidenciado nos últimos tempos: o Empoderamento.

Uma livre tradução do termo em inglês Empowerment, o conceito vem ganhando espaço nas discussões feministas e tem sido bastante utilizado e problematizado ${ }^{7}$ nos últimos anos. A ideia de empoderamento está diretamente relacionada ao reconhecimento das restrições sociais que determinados grupos sofrem - como no caso das mulheres e de suas diferentes características que acabam por colocá-las em situação de discriminação - e a necessidade de transformação nessa conjuntura. Segundo Cortez e Souza (2008), a reversão dessa situação pode se dar por meio de mudanças tanto em um contexto mais amplo, como na vida pública, através da inserção de mulheres em cargos de poder e decisão, por meio de uma educação não sexista e ainda mediante serviços de saúde adequados; quanto em contextos mais específicos (ou individuais), como o

\footnotetext{
${ }^{7}$ Movimento que vem reconhecidamente acontecendo nas redes sociais, a problematização de determinados termos que se popularizam e ganham significados variados traz para a academia o desafio de acompanhar as diferentes discussões que acontecem muitas vezes de maneira bastante rápida. Empoderamento e Sororidade são termos que foram apropriados por uma linguagem liberal que os utiliza, muitas vezes, de maneira irresponsável e completamente imbuída de uma individualidade que fere a etimologia própria dessas palavras. Neste trabalho, optou-se por continuar utilizando os dois termos fazendo menção à necessidade de entende-los a partir de uma lógica pautada na coletividade e em como estes conceitos podem servir como motes de transformação social.

Revista Tópicos Educacionais, Pernambuco, v. 27, n. 01, p.34-61, 2021. ISSN: 2448-0215. https://periodicos.ufpe.br/revistas/topicoseducacionais/index Dossiê "Conflitos, violências, bullying na escola: problemas da convivência potencializado pela pandemia?" DOI: 10.51359/2448-0215.2021.250294
} 
aumento da autoestima, da autonomia, estabelecendo mudanças efetivas na reorganização do trabalho doméstico, entre outros.

Para Horochovski e Meirelles (2007), o sentido de empoderamento se assemelha à noção de autonomia, pois confere aos indivíduos e grupos o poder de decisão sobre as questões que lhes são caras nas mais variadas esferas (política, econômica, cultural, psicológica, etc.). Assim, podese conceber o empoderamento enquanto resultado de processos políticos a nível individual e/ou coletivo que tornam possível o agenciamento de voz, visibilidade e capacidade de ação dos sujeitos (HOROCHOVSKI; MEIRELLES, 2007).

O empoderamento de meninas tem a ver com a consciência que essas meninas têm de sua condição de mulher numa sociedade misógina, portanto numa sociedade em que, de modo geral, lhe foi negado protagonismo de pensamento e sentimento, e lhe foi oferecido um espaço de adequação pré-moldado. Meninas empoderadas tendem a não ser "adequadas" a papeis que fixam seus traços identitários, fazendo-as parecer imóveis diante da vida. E esse empoderamento também se torna possível graças à capacidade de superação das adversidades causadas por essa condição social de desigualdade.

\section{Resiliência e Educação}

Resiliência é uma ferramenta de autorregulação interna que possibilita a habilidade de adaptação e enfrentamento de problemas. É a capacidade universal que viabiliza o indivíduo a, passando por uma situação de risco, enfrentar e superar as adversidades a partir de estratégias de resolução de conflitos, comunicação clara e gestão de pensamentos e sentimentos. Muitas vezes superficialmente lida como uma simples "capacidade de superação", a resiliência é um processo mais complexo que necessita, do indivíduo e do ambiente que ele está inserido, um terreno fértil para se desenvolver, o que pode lhe fugir ao controle e exigir muito mais em sua prática.

Fajardo, Minayo e Moreira (2010) colocam que o sentido de resiliência vai muito além do que o que lhe é dado, apresentando duas dimensões que ele comporta: na primeira, resiliência se apresenta enquanto uma resistência à destruição, uma aptidão que desenvolve-se na intenção de proteger a integridade em momentos de forte pressão; já a segunda dimensão dá conta da

Revista Tópicos Educacionais, Pernambuco, v. 27, n. 01, p.34-61, 2021. ISSN: 2448-0215. https://periodicos.ufpe.br/revistas/topicoseducacionais/index Dossiê "Conflitos, violências, bullying na escola: problemas da convivência potencializado pela pandemia?" DOI: $10.51359 / 2448-0215.2021 .250294$ 
capacidade de construção, de recriação de uma vida digna independente das circunstancias adversas, ou até mesmo por causa delas (FAJARDO; MINAYO; MOREIRA, 2010).

Larrosa (2008) acredita que a resiliência seria um recurso, parte inato e parte desenvolvido ao longo da vida. Algumas pessoas, devido à sua vivência, elaboram processos de resiliência com mais naturalidade, enquanto outras precisam de apoio. Sendo assim, a autora define resiliência como “(...)a capacidade para desenvolver-se bem, para continuar projetando-se no futuro apesar dos acontecimentos desestabilizadores, de condições de vida difíceis e de traumas às vezes graves" (LARROSA, 2008, p. 251). É ter habilidade para lidar, solucionar, ganhar conhecimento e ser transformado a partir das adversidades, sem deixar que seus efeitos nocivos lhes impeçam de continuar.

Boris Cyrulnik, neurologista, psiquiatra e psicanalista francês defende a ideia de que qualquer pessoa pode vir a ser resiliente (CYRULNIK, 2004). O autor acredita que as crianças que se desenvolvem de forma saudável na primeira infância, especialmente em questões ligadas a apego, bem como os comportamentos cativantes em seu meio, processam as emoções de maneira mais efetiva. Porém, ainda que a criança não passe por este cenário, ela pode "criar asas", desde que tenha alguém na forma de um adulto resiliente, que aja como um tutor nesse aspecto, priorizando o ambiente seguro que deverá ser criado ao redor dela.

Corroborando com essa premissa, Peltz, Moraes e Carlotto (2010) pontuam que os/as jovens são conduzidos à idade adulta atravessando várias arenas sociais, a exemplo da família, do seu contexto social, cultural, histórico e geográfico particular, dos sistemas educacionais e de relacionamentos construído com seus pares, além de ambientes de trabalho e etc. A conexão dessas arenas entre si, em sua estrutura e função, é de extrema importância para que o/a jovem consiga enxergar a vida como coerente (PELTZ; MORAES; CARLOTTO, 2010). A ideia de um ambiente que conceba esse/a jovem como um ser humano completo, que deve ser respeitado e visto por quem é, a partir do diálogo reflexivo entre o seu ser e o espaço em que está inserido/a, bem como os fatores externos como segurança, e dignidade, são essenciais para o desenvolvimento dessa resiliência.

Pesce et al (2004) faz uma distinção entre os fatores de risco e os fatores protetores a que essas crianças e jovens podem estar imersos. Sobre o risco, a autora comenta que "condições de pobreza, rupturas na família, vivência de algum tipo de violência, experiências de doença no próprio indivíduo ou na família e perdas importantes são alguns exemplos” (PESCE et al, 2004, p.

Revista Tópicos Educacionais, Pernambuco, v. 27, n. 01, p.34-61, 2021. ISSN: 2448-0215. https://periodicos.ufpe.br/revistas/topicoseducacionais/index Dossiê "Conflitos, violências, bullying na escola: problemas da convivência potencializado pela pandemia?" DOI: 10.51359/2448-0215.2021.250294 
136). Esses eventos considerados como risco para crianças e adolescentes aumentam sua vulnerabilidade gerando resultados negativos em seu desenvolvimento. Ainda que experiências negativas sejam inevitáveis na vida de todas as pessoas, chama-se atenção aqui para o nível de exposição à essas situações, bem como aos limites individuais de cada um. Dessa forma, o que classifica uma situação como estressante é a visão subjetiva, a percepção e o sentido atribuído pelos indivíduos a ela (PESCE et al, 2004).

Já sobre os fatores protetores, a autora pontua que processos de proteção se caracterizam por conseguir provocar modificações na resposta dos indivíduos aos fatores de risco. Para elucidar a questão, classifica em quatro as principais funções desses fatores: (1) redução do impacto dos riscos, (2) redução de reações negativas que a exposição ao risco gera nos indivíduos, (3) estabelecimento e manutenção da autoestima e da autoeficácia a partir da disposição de relações de apego seguras e, por fim, (4) a criação de oportunidades que revertam os efeitos das situações de estresse (PESCE et al, 2004).

Naturalmente, os sujeitos estão constantemente sendo confrontados por situações de mudanças, o que exige deles uma maior flexibilidade cognitiva para que a adaptação aconteça de forma saudável. Diante da importância de tal característica, cabem alguns questionamentos: como desenvolver resiliência de modo que, passando por todas as situações e vivendo todas as demandas que a sociedade contemporânea implica, consiga-se progredir e prosperar enquanto pessoas sãs? Como auxiliar crianças e adolescentes no desenvolvimento e fortalecimento da resiliência?

Para discutir a questão com mais profundidade, é preciso direcionar um olhar mais acurado também para a escola. Tavares (2001) defende a tese de que a capacidade de resiliência pode ser desenvolvida não apenas em pessoas, mas também em organizações, em prol da construção de uma nova ordem social. Fajardo, Minayo e Moreira (2010) acreditam que o estímulo à resiliência no ambiente escolar é importante não só por estabelecer vínculos de sociabilidade, como também promovendo atitudes e comportamentos positivos, o que evita o isolamento social e, consequentemente, outros problemas graves como violência e discriminação. Depois da família, é a escola que se apresenta enquanto espaço essencial de aprendizagem das ferramentas que auxiliarão as crianças e adolescentes na superação das adversidades da vida. Dessa forma, aprender a promover a resiliência faz parte das competências de uma boa educação escolar e deve ser objetivo fundamental na formação dos indivíduos. (FAJARDO; MINAYO; MOREIRA, 2010).

Revista Tópicos Educacionais, Pernambuco, v. 27, n. 01, p.34-61, 2021. ISSN: 2448-0215. https://periodicos.ufpe.br/revistas/topicoseducacionais/index Dossiê "Conflitos, violências, bullying na escola: problemas da convivência potencializado pela pandemia?" DOI: 10.51359/2448-0215.2021.250294 
Ao levar-se em conta a situação de crianças e adolescentes que não possuem laços familiares bem construídos, fica ainda mais evidente o papel da escola como um ambiente que tem a responsabilidade de propiciar o desenvolvimento de resiliência e proteção para seus/suas alunos/as. Sousa et al (2014) acreditam que uma escola que tem por intenção a educação para a resiliência necessita estabelecer e manter viva uma rede com pais e outros membros familiares dos/as aluno/as, com o propósito de construir um sentido de comunidade no espaço escolar, priorizando a comunicação com dignidade e respeito em bases cotidianas. Os autores pontuam que “a combinação das altas expectativas e o apoio adequado proporcionarão aos alunos uma melhor autoeficácia, autoestima e otimismo" (SOUSA et al., 2014, p. 31).

E, para tal, faz-se necessário também trazer a discussão para o campo das emoções, rompendo a dicotomia entre cognição $\mathrm{x}$ afetividade em que o atual sistema escolar está fundamentado. Pensando nessa questão, Arantes (2002) defende a ideia de um currículo que abarque também conteúdos considerados pessoal ou da vida privada, de maneira integrada com o conteúdo das disciplinas clássicas como matemática, línguas, ciências e etc. Quebrando-se a barreira entre as questões de afeto e cognição, tratando-as não como opostos, mas como complementares entre si, assume-se que dentro da sala de aula, a afetividade aparece como instrumento que pode ser utilizado pelo/a jovem na construção de uma postura segura e empoderada de si e de seus traços identitários. Sendo o ser humano fruto de suas experiências com o mundo que o cerca, o impacto dessas interações é determinante em sua constituição como indivíduo.

Intenta-se aqui pensar o empoderamento das meninas não como um sinônimo de resiliência, mas como dois processos distintos de um mesmo caminho, sendo meio e fim em si próprio, mas que interagem na sua forma básica. Combinar o conceito de resiliência com o de empoderamento significa entender que alguém resiliente não é alguém forte o tempo inteiro, não é alguém que não chora, não sofre, não sente raiva. É entender que pessoas resilientes o são por passarem por todas as situações anteriores sem se perder no meio delas, sem deixá-las tomar conta e mudar quem intrinsecamente são.

O empoderamento entra nessa situação como um canal para que essa resiliência se firme. Os processos de empoderamento são como uma formação político-cultural-social de cada indivíduo ou grupo de pessoas, que influencia em como elas se enxergam, em como leem o mundo

Revista Tópicos Educacionais, Pernambuco, v. 27, n. 01, p.34-61, 2021. ISSN: 2448-0215. https://periodicos.ufpe.br/revistas/topicoseducacionais/index Dossiê "Conflitos, violências, bullying na escola: problemas da convivência potencializado pela pandemia?" DOI: $10.51359 / 2448-0215.2021 .250294$ 
e se colocam nele. Nesse contexto, os processos de resiliência chegam como um curativo nas rachaduras provocadas pelo caminho trilhado antes dessa visão empoderadora.

\section{MATERIAIS E MÉTODOS}

A pesquisa que gerou este artigo foi fundamentada numa abordagem qualitativa e possui um caráter tanto teórico quanto empírico, amparando-se assim nessas duas modalidades de investigação. A abordagem qualitativa garante à análise dos dados, posição crítico-reflexiva e possibilita que os resultados sejam discutidos, tendo como premissa processos dialógicos, além de visar transmitir as nuances subjetivas do comportamento humano.

O trabalho empírico aqui apresentado foi organizado com a aplicação de duas técnicas: (1) aplicação de questionário e (2) realização de rodas de diálogo. O lócus foi uma Escola de Referência em Ensino Médio (EREM) da cidade do Recife (2017).

Nesse sentido, na aplicação da primeira técnica, a adesão foi voluntária. Havia 156 adolescentes matriculadas na escola, divididas em duas turmas de primeiro ano, duas de segundo ano e duas de terceiro ano. Dessas 156 meninas, 91 participaram. O primeiro grupo ( $1^{\circ}$ ano) contou com a participação de 38 meninas, o segundo ( $2^{\circ}$ ano) com 32 meninas e o terceiro ( $3^{\circ}$ ano) com 21 meninas. O questionário foi composto por quatro blocos temáticos: Bullying, Escola, Resiliência e Gênero. Ele foi desenvolvido de modo a identificar, primordialmente, quem era alvo/autora/expectadora de bullying, e contou com 26 questões, sendo 3 delas abertas. A aplicação dessa técnica foi essencial para se ter um panorama mais geral de como as meninas compreendiam, conheciam e reconheciam o fenômeno bullying e suas possíveis implicações.

Para a segunda etapa da pesquisa, utilizou-se a técnica de Rodas de Diálogo, sendo esta uma metodologia de participação coletiva, que gera debates sobre determinada temática, na intenção de que os sujeitos participantes possam se expressar e escutar seus pares. O objetivo principal dessa técnica de pesquisa é incentivar a construção da autonomia tendo como caminho a problematização, a socialização dos diferentes saberes e a reflexão com foco na ação (NASCIMENTO E SILVA, 2009).

A realização das rodas de diálogo foi dividida em quatro encontros, que aconteceram com uma turma por vez e tiveram por objetivo novamente discutir os eixos centrais da pesquisa:

Revista Tópicos Educacionais, Pernambuco, v. 27, n. 01, p.34-61, 2021. ISSN: 2448-0215. https://periodicos.ufpe.br/revistas/topicoseducacionais/index Dossiê "Conflitos, violências, bullying na escola: problemas da convivência potencializado pela pandemia?" DOI: 10.51359/2448-0215.2021.250294 
Bullying, Escola, Resiliência e Gênero. Para este momento, foram selecionadas 45 meninas: 18 dos primeiros anos, 13 dos segundos anos e 14 dos terceiros anos. Essas meninas foram selecionadas em razão de, em seus questionários, ter sido identificado a incidência de bullying como autora ou alvo, bem como movimentos de empoderamento e resiliência.

Todos os encontros referentes às rodas de diálogo tiveram seus áudios gravados (gravador digital), utilizou-se um caderno para tomar notas de pontos observados nas rodas. As participantes eram livres para retirar sua participação a qualquer momento, bem como para não responder qualquer questão que as deixassem desconfortáveis. A identidade das participantes, mediante acordo de confidencialidade, manteve-se anônima.

\section{RESULTADOS E DISCUSSÃO}

Os resultados a seguir serão apresentados a partir de uma separação de acordo com as etapas de pesquisa propostas. Na primeira etapa da pesquisa empírica, das 146 meninas regularmente matriculadas na escola, 91 estavam presentes no dia da aplicação do questionário e se disponibilizaram a participar. Na segunda parte, as 45 meninas selecionadas para participar das rodas de diálogo apresentaram uma taxa de ausência entre 15 e 30\%, levando-se em consideração os 4 encontros com cada turma, porém não houve prejuízo para a discussão e coleta de dados. Nesta sessão, irá se destrinchar as questões encontradas em campo de maneira a ilustrar os dados da forma mais precisa

\section{Primeira Etapa: Questionários}

O Gráfico 1 exibe a parcela de meninas que declararam ter sofrido ou não bulliyng na escola. Através dele, observa-se que mais da metade das meninas entrevistadas (70,33\%) já vivenciaram o fenômeno, ao passo que $29,67 \%$ delas não sofreram. O que redimensiona a pesquisa do PISA $2015^{8}$ que afirma ser $17,2 \%$ o percentual de crianças e adolescentes brasileiros/as envolvidos/as com bullying pelo menos três vezes no mês em todas as escolas brasileiras. Ao

\footnotetext{
8 
Revista Tópicos Educacionais

Revista do Programa de Pós-Graduação em Educação

da Universidade Federal de Pernambuco (UFPE)

contrário do que se costumou pensar, o bullying não é um fenômeno raro, ele tem sido certamente um dos fenômenos de violência mais comuns e frequentes em instituições de ensino.

\section{Gráfico 1 - Você já sofreu algum tipo de bullying na escola? (\%)}

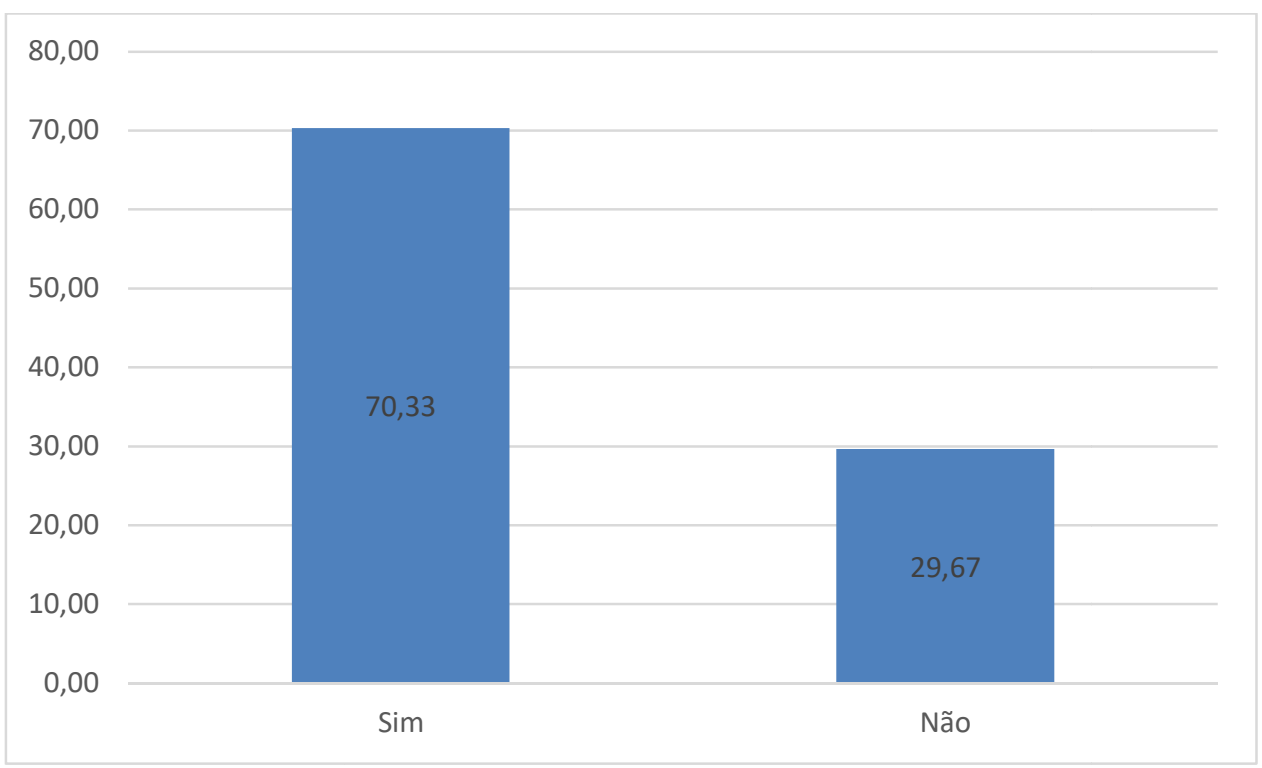

Fonte: Elaboração própria a partir dos dados coletados em campo.

As perguntas de 2 a 8 no questionário apresentam respostas somente das meninas que se posicionaram sobre já terem sofrido bullying na escola, ou seja, as 70,33\% apontadas no gráfico anterior. Quando perguntado sobre a última vez que haviam sofrido bullying, metade delas (50\%) afirma que ocorreu no último ano; $26,56 \%$ optaram por não responder; $15,63 \%$ delas declararam que foi no último mês; 4,69\% que foi na última semana; e 3,13\% falaram que no dia da entrevista alguém já havia praticado bullying com elas.

$\mathrm{Na}$ etapa das rodas de diálogo, entendeu-se que muitas delas tinham dificuldades de se enxergar enquanto alvo recentemente, sendo necessário uma maior explicação do conceito de bullying e um processo de autorreflexão para que conseguissem. Isso pode explicar o porquê de uma porcentagem tão grande (50\%) dizer que só ocorreu no último ano. Também chama atenção o fato de $26,56 \%$ optarem por não responder. É importante que fique evidente o quanto é difícil para crianças e adolescentes falarem sobre o que lhes acontece entre seus pares e como elas têm dificuldade de lidar com a violência. Um dos maiores problemas na detecção do fenômeno é o fato

Revista Tópicos Educacionais, Pernambuco, v. 27, n. 01, p.34-61, 2021. ISSN: 2448-0215. https://periodicos.ufpe.br/revistas/topicoseducacionais/index Dossiê "Conflitos, violências, bullying na escola: problemas da convivência potencializado pela pandemia?" DOI: $10.51359 / 2448-0215.2021 .250294$ 
Revista Tópicos Educacionais

Revista do Programa de Pós-Graduação em Educação

da Universidade Federal de Pernambuco (UFPE)

de que as pessoas alvo silenciam por medo e por, muitas vezes, ignorarem que seus direitos estão sendo aviltados.

Quanto à prática do bullying, 69,66\% das entrevistadas informaram que nunca praticou; $25,84 \%$ delas declararam ter praticado somente uma ou duas vezes; 3,37\% praticaram algumas vezes no decorrer do último ano; e 1,12\% declararam praticar bullying todos os dias (Gráfico 2). O alto índice de meninas que afirma nunca ter praticado bullying também denuncia, assim como na questão sobre sofrer, que algumas delas não conseguem se reconhecer enquanto autoras. No decorrer da pesquisa, ficou evidente que muitas achavam que estavam "brincando" e não conseguiam identificar o sofrimento alheio a partir de seus atos. $\mathrm{O}$ fato de haver pouca discussão sobre o fenômeno na ambiência escolar pode levar à ignorância ou indiferença sobre o outro.

\section{Gráfico 2 - Você já praticou bullying com alguma colega? (\%)}

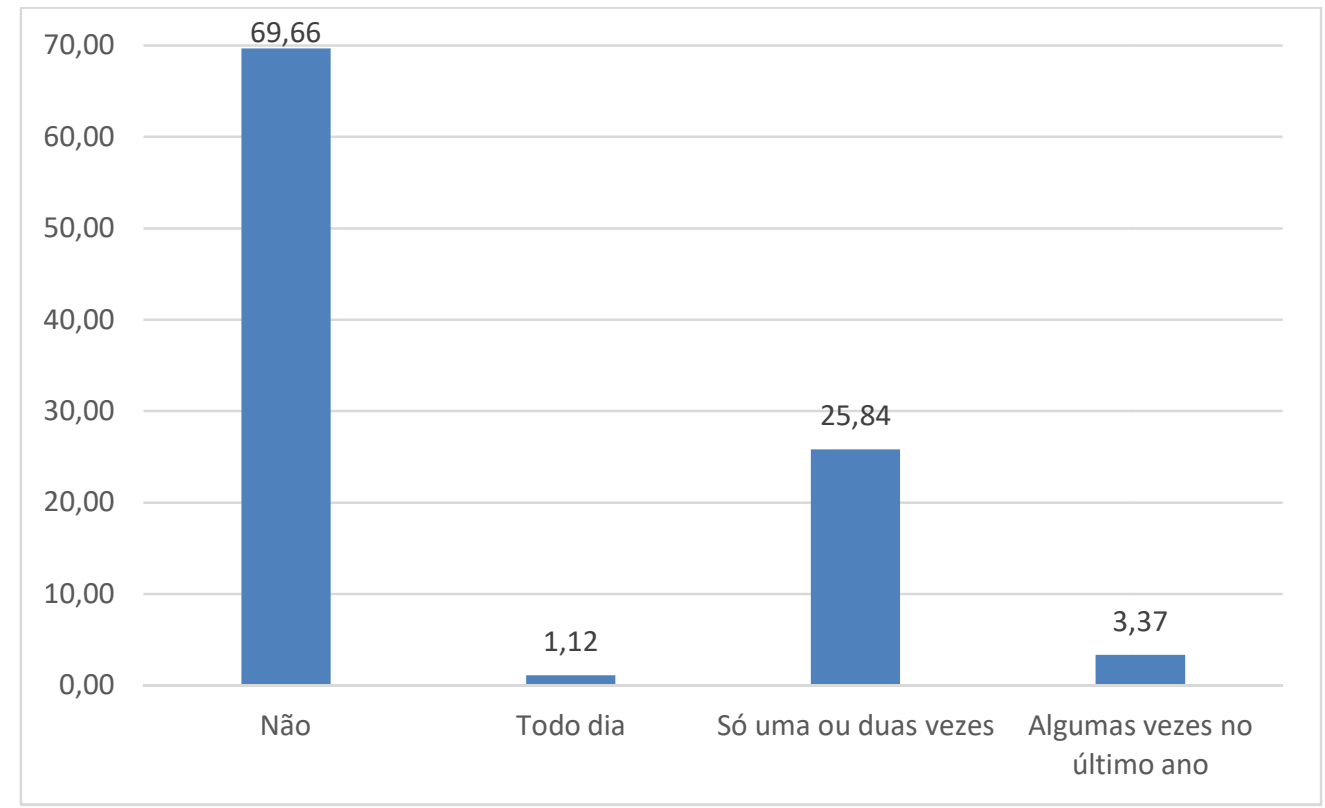

Fonte: Elaboração própria a partir dos dados coletados em campo.

Das 30.34\% que declararam já ter cometido bullying contra alguma colega, 92,59\% colocaram apelidos, xingaram ou excluiram, ao passo que 7,41\% bateram, deram pontapés. Esse dado corrobora a literatura que aponta o bullying entre meninas como predominantemente indireto, sem chegar a acontecer na forma física (BANDEIRA, 2009; BANDEIRA; HUTZ, 2012).

Revista Tópicos Educacionais, Pernambuco, v. 27, n. 01, p.34-61, 2021. ISSN: 2448-0215. https://periodicos.ufpe.br/revistas/topicoseducacionais/index Dossiê "Conflitos, violências, bullying na escola: problemas da convivência potencializado pela pandemia?" DOI: 10.51359/2448-0215.2021.250294 
Revista Tópicos Educacionais

Revista do Programa de Pós-Graduação em Educação

da Universidade Federal de Pernambuco (UFPE)

Gráfico 3 - Resiliência é a capacidade que nós temos de reagir perante as adversidades da vida e conseguir se restabelecer. Você se considera uma pessoa resiliente? (\%)

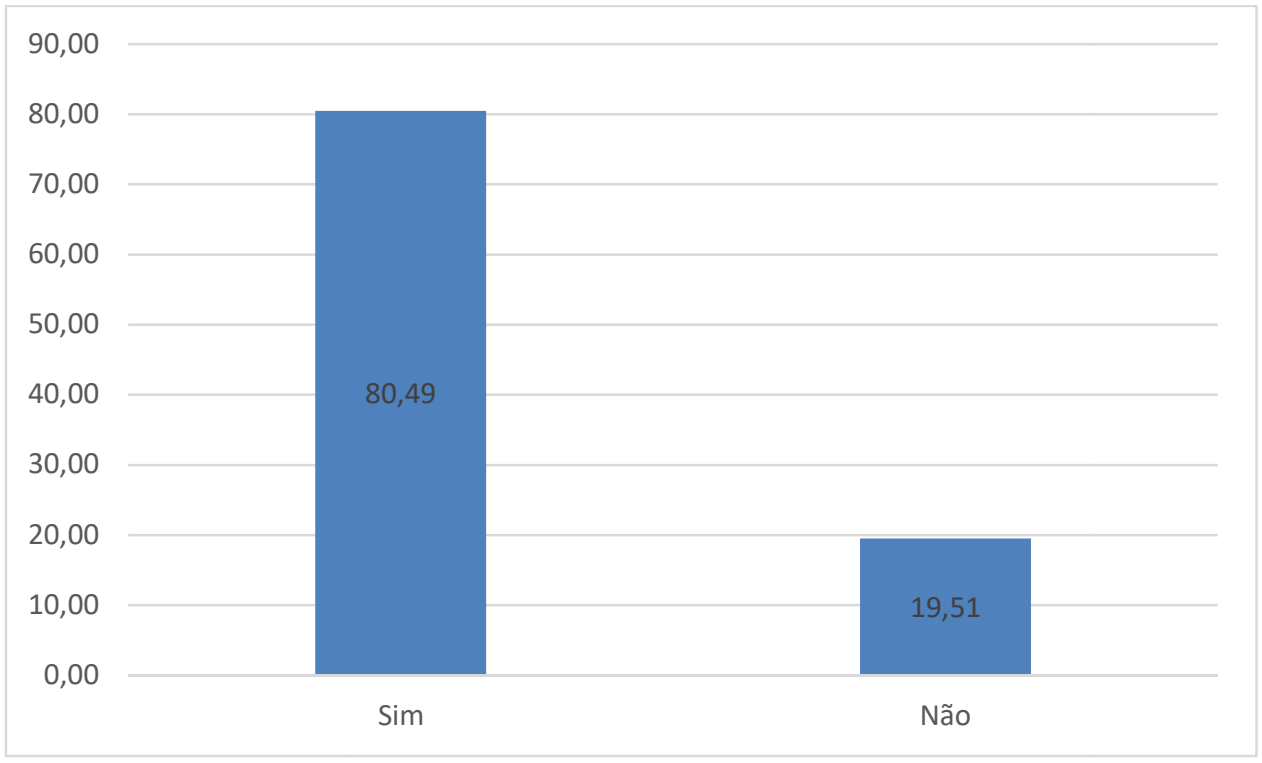

Fonte: Elaboração própria a partir dos dados coletados em campo.

Em relação a resiliência, $80,49 \%$ das meninas que responderam o questionário se consideram uma pessoa resiliente. Ao analisar-se o Gráfico 3, vê-se que o alto percentual de meninas que se dizem resilientes coincide com as respostas sobre estilo de vida que elas deram às perguntas contidas no Gráfico 4.

Revista Tópicos Educacionais, Pernambuco, v. 27, n. 01, p.34-61, 2021. ISSN: 2448-0215.

https://periodicos.ufpe.br/revistas/topicoseducacionais/index

Dossiê "Conflitos, violências, bullying na escola: problemas da convivência potencializado pela pandemia?" DOI: $10.51359 / 2448-0215.2021 .250294$ 
Revista Tópicos Educacionais

Revista do Programa de Pós-Graduação em Educação da Universidade Federal de Pernambuco (UFPE)

\section{Gráfico 4 - Das situações listadas abaixo quais você faz/pratica? (\%)}

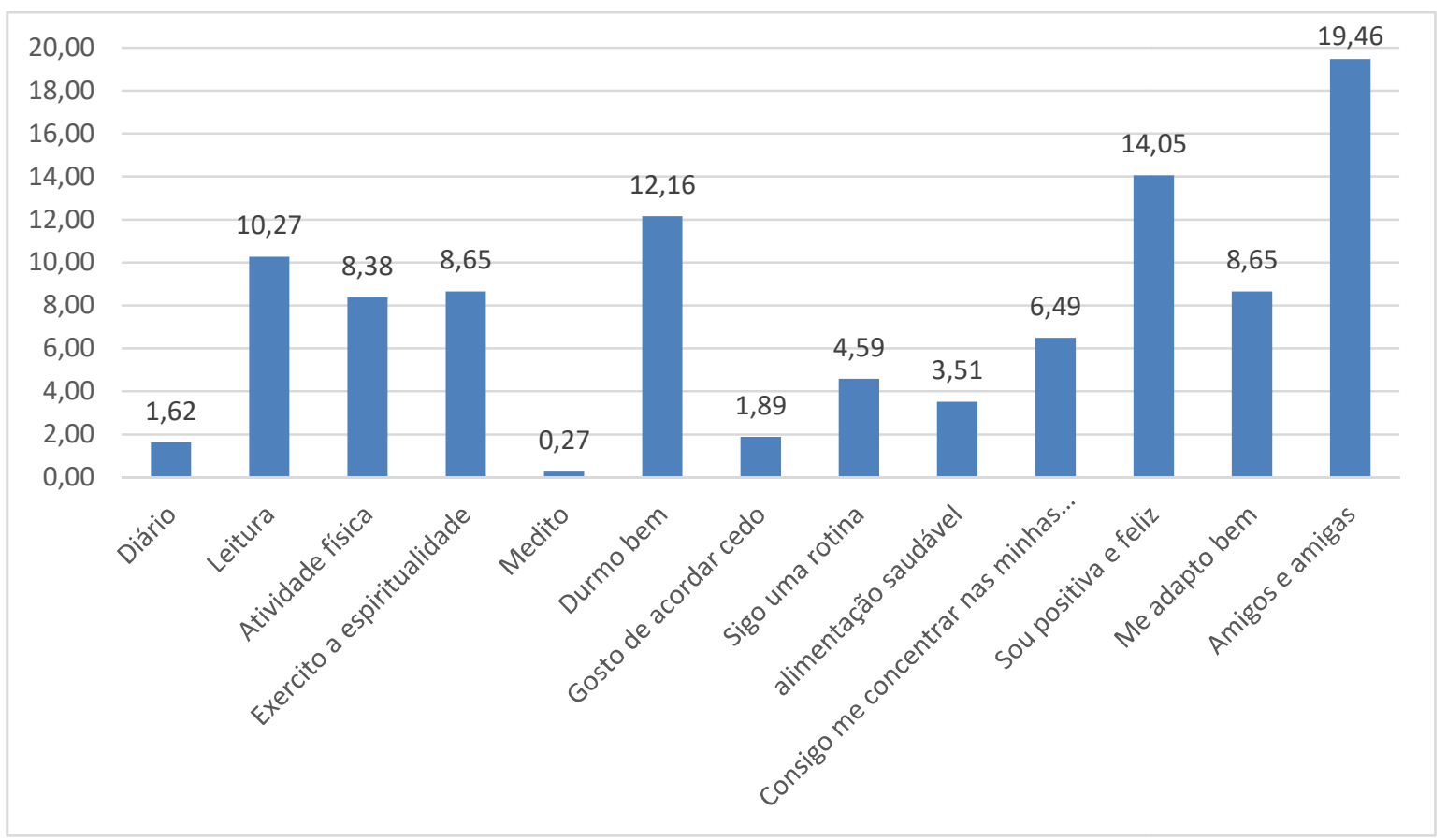

Fonte: Elaboração própria a partir dos dados coletados em campo.

Legenda: A) Mantenho um diário; B) Leio com frequência; C) Faço atividade física; D) Exercito minha espiritualidade; E) Medito; F) Durmo bem; G) Gosto de acordar cedo; H) Tenho uma rotina consistente que me faz bem; I) Mantenho uma alimentação saudável; J) Consigo me concentrar nas atividades que desempenho sem maiores problemas; K) Normalmente sou uma pessoa positiva e feliz; L) Não costumo ter problemas para me adaptar em situações fora da minha zona de conforto; M) Tenho amigos e amigas com quem posso contar.

Foi perguntado também sobre situações rotineiras e atividades cotidianas praticadas pelas entrevistadas, e para essa questão elas podiam responder mais de uma alternativa. A maioria afirmou ter amigos e amigas com quem pode contar; $14,05 \%$ se declararam enquanto alguém geralmente positiva e feliz; $12,16 \%$ dormiam bem; $10,27 \%$ liam com frequência; $8,65 \%$ exercitavam sua espiritualidade; a mesma porção $(8,65 \%)$ não costumavam ter problemas de adaptação em situações fora de sua zona de conforto; 8,38\% realizavam atividade física; 6,49\% conseguiam se concentrar sem maiores problemas; $4,59 \%$ seguiam uma rotina consistente que a faz bem; 3,51\% mantinham uma alimentação saudável; 1,89\% gostavam de acordar cedo; 1,62\% mantinham um diário; e 0,27\% meditavam (Gráfico 4).

A resiliência que se experimenta no processo da vida e que ajuda a viver com maior capacidade de resistir e de existir tem a ver com a maneira como elementos externos e internos estão relacionados à essa vivencia. Em outras palavras, um amigo, uma amiga, pode ser um Revista Tópicos Educacionais, Pernambuco, v. 27, n. 01, p.34-61, 2021. ISSN: 2448-0215. https://periodicos.ufpe.br/revistas/topicoseducacionais/index Dossiê "Conflitos, violências, bullying na escola: problemas da convivência potencializado pela pandemia?" DOI: 10.51359/2448-0215.2021.250294 
diferencial na vida de meninas que atravessam situações de bullying em seu cotidiano escolar. Fazer atividades físicas, dormir e se alimentar bem são fundamentais para que uma pessoa possa enfrentar o cotidiano da vida de modo mais esperançoso. O elemento espiritualidade e leitura também figuram como essenciais na construção de pensamentos resilientes, isto é, pensamentos que conseguem enfrentar os desafios.

A pergunta que é representada no gráfico abaixo (Gráfico 5) pode ser respondida com mais de uma alternativa. Nela, $52,88 \%$ das meninas entrevistadas declararam já ter passado por crises de ansiedade; $16,35 \%$ já sofreram ataques de pânico; $14,42 \%$ já tiveram depressão; e 16,35\% nunca passaram por nenhuma dessas situações.

Os dados demonstram que as meninas estão experimentando processos de adoecimento e que tais processos podem estar relacionados também (como se vê na segunda etapa) às experiências de violência vividas na ambiência escolar. Segundo Fante e Pedra (2008), é notório que as práticas de bullying podem acarretar consequências graves e até irreparáveis para as pessoas alvo, os/as autores/as e até para os/as expectadores. Essas consequências podem vir a curto ou longo prazo, causando dificuldades a nível acadêmico, social ou emocional, além de provocar depressão e baixa autoestima perdurando até a idade adulta (FANTE; PEDRA, 2008)

\section{Gráfico 5 - Por quais situações abaixo você já passou? (\%)}

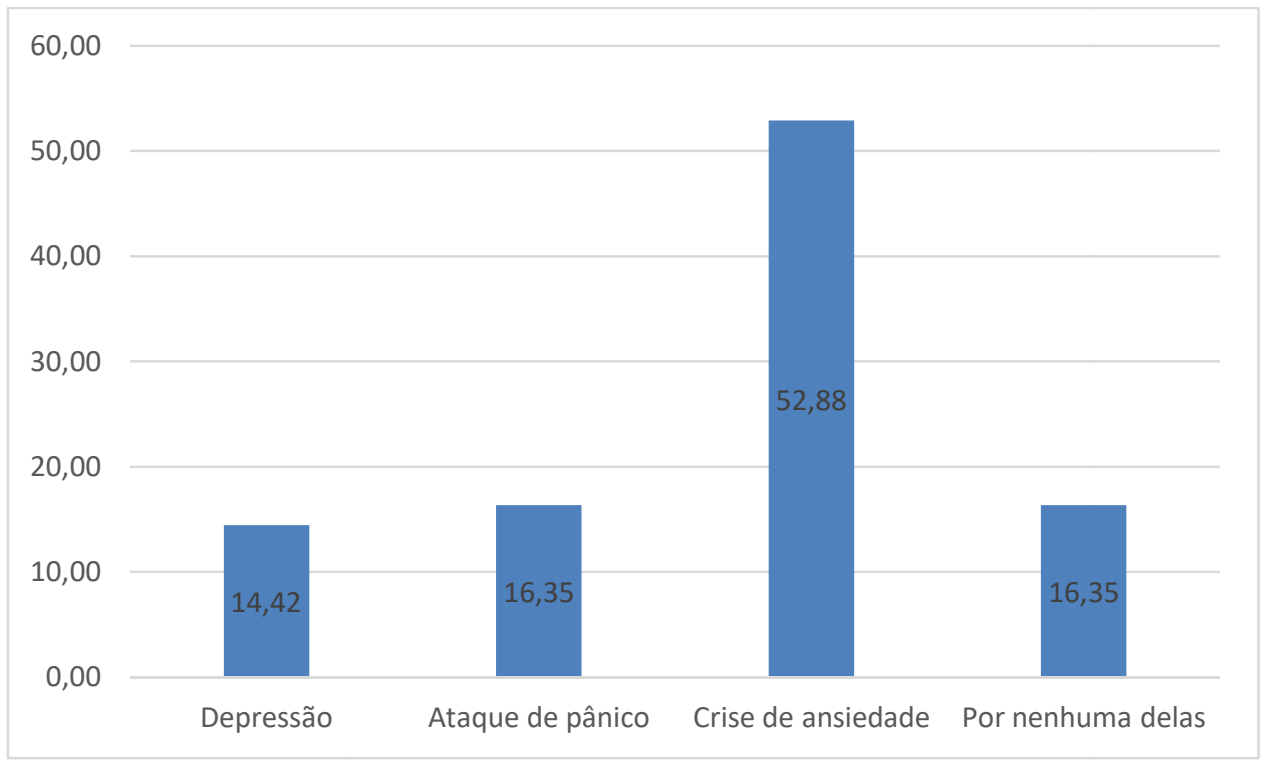

Fonte: Elaboração própria a partir dos dados coletados em campo.

Revista Tópicos Educacionais, Pernambuco, v. 27, n. 01, p.34-61, 2021. ISSN: 2448-0215. https://periodicos.ufpe.br/revistas/topicoseducacionais/index Dossiê "Conflitos, violências, bullying na escola: problemas da convivência potencializado pela pandemia?" DOI: $10.51359 / 2448-0215.2021 .250294$ 


\section{Revista Tópicos Educacionais}

No que se refere à discriminação de gênero e por orientação sexual, 69,88\% disseram que nunca sofreram, e $30,12 \%$ alegaram já ter sofrido esse tipo de preconceito. Dentre as que afirmaram que sim, a maioria aponta o machismo como causa. Os dados demonstram que a maior parcela diz não ter sido alvo de discriminação entre elas, mas também evidenciam que um percentual considerável reconhece que foi e que sabe qual foi a causa da discriminação. Esse fato parece sinalizar um avanço nas discussões acerca da temática, movimento que vem reconhecidamente sendo impulsionado pelas discussões em redes sociais ${ }^{9}$. Além disso, na etapa seguinte desta pesquisa, fica evidente que o baixo índice de meninas que afirma nunca ter sofrido discriminação de gênero está relacionado a um desconhecimento acerca do que essa discriminação representa.

Segunda Etapa: Rodas de Diálogo

Nesta segunda etapa da parte empírica, houve uma aderência muito grande à metodologia proposta, praticamente todas as meninas se colocaram em algum momento. Não era necessário conhecimento prévio sobre nenhum tema, as discussões foram seguidas de forma intuitiva, para que elas colocassem questões do seu dia-a-dia. Levantou-se questões que incitaram uma reflexão sobre si, sobre a outra e sobre o espaço em que estavam inseridas, cultural e socialmente.

Dessa forma, ao se iniciar a discussão sobre bullying, pode-se constatar o que a literatura (BANDEIRA; HUTZ, 2012; MALDONADO, 2011; FANTE, 2005) aponta, já que as exposições dão conta de um bullying majoritariamente indireto, porém, não raro também foram ouvidos relatos de intimidação de maneira bastante incisiva, como violação de bem pessoais e ameaças físicas.

Teve até um caso que aconteceu comigo aqui no colégio ano passado. Todo dia eu trazia biscoito. Todo dia, ai ta... Um dia, uma menina daqui chegou e disse 'cadê o biscoito?' e meteu a mão na minha bolsa. Ai eu deixei passar. Quando foi depois, eu abri a bolsa e tinham tirado o dinheiro da minha passagem. Deixei passar. Quando foi depois, começaram a rasgar meu caderno, depois chegaram ao extremo de rasgar a minha bolsa. Aí eu fiquei arretada e fui falar com a gestão.

\footnotetext{
${ }^{9}$ Para um maior aprofundamento sobre este ponto, ver: COELHO, Mayara Pacheco. Vozes que ecoam: Feminismo e Mídias Sociais. Pesquisas e Práticas Psicossociais. V. 11, n. 1. São Joao Del Rei, 2016.

Revista Tópicos Educacionais, Pernambuco, v. 27, n. 01, p.34-61, 2021. ISSN: 2448-0215. https://periodicos.ufpe.br/revistas/topicoseducacionais/index Dossiê "Conflitos, violências, bullying na escola: problemas da convivência potencializado pela pandemia?" DOI: $10.51359 / 2448-0215.2021 .250294$
} 
Tinha uma menina aqui no colégio que ficava com um menino que eu gostava. Aí quando eles acabaram ela esbarrava em mim e se limpava, na minha frente, assim... Na frente de todo mundo.

(...) E quando um menino que era colega dela vinha falar comigo, quando ele ia tocar nela ela mandava ele não tocar porque tinha nojo de mim. (...) Ela já falou pra outro amigo dela que queria me encontrar na escola sozinha pra me empurrar da escada. (...) Ela dizia que ia acabar com meu namoro e fazer da minha vida um inferno.

Uma frase que apareceu em quase todas as rodas foi "é melhor ser amiga dos meninos que das meninas". Visto que esse pareceu ser um pensamento geral, independente da turma, foi pedido para que elas desenvolvessem esse raciocínio e ao serem perguntadas o porquê de acharem isso, colocam que:

Não são todos, mas têm uns que são mais receptivos. Eles param e você consegue conversar com eles. Eles são mais abertos a isso. Enquanto as meninas, elas são mais assim... Já começam a rir, a cochichar com a outra.

Ficou evidente que existe um problema em como as meninas enxergam umas às outras. Suas falas estão arraigadas do senso comum que tipifica todas as mulheres como fofoqueiras, invejosas ou falsas. Perguntadas sobre o porquê da situação se configurar dessa maneira, elas colocaram que existe uma competição muito grande entre meninas, que é assim em todo canto e essa competição se dá majoritariamente tendo os meninos como pivô, porém não apenas por esse motivo. Muitas vezes, questões como notas, prestígio social e beleza também aparecem como razão para desencadear um problema neste cenário.

A gente não foi um primeiro ano muito quietinho, a gente já chegou se metendo em tudo, participando de tudo. Se a gente subisse pra cá o povo do segundo ano já arrumava uma briga: 'no meu primeiro ano não tinha isso de ficarem no nosso corredor' (...) e quem falava isso? As meninas! (...) Se os meninos do segundo ano falassem com as meninas do primeiro elas ficavam com raiva!

Revista Tópicos Educacionais, Pernambuco, v. 27, n. 01, p.34-61, 2021. ISSN: 2448-0215. https://periodicos.ufpe.br/revistas/topicoseducacionais/index Dossiê "Conflitos, violências, bullying na escola: problemas da convivência potencializado pela pandemia?" DOI: $10.51359 / 2448-0215.2021 .250294$ 
Existe de maneira muito clara a ideia que a relação entre mulheres é sempre baseada numa tensão inicial que exige um constante alerta em direção à outra, diferente dos meninos, que em suas relações com seus pares sempre conseguiriam construir uma ligação baseada na irmandade. Desde a mais tenra idade essa ideia se fundamenta e molda a maneira como as meninas se conectam.

Outro ponto que foi evidenciado nas discussões é a ideia de que quando uma menina é amiga de um menino este não fala mal dela. A premissa de "melhor ser amiga deles do que falarem de mim" se fez presente em determinados momentos, especialmente no grupo das mais novas. A intenção de se proteger faz muito sentido quando se entende o poder que os meninos têm estabelecido nesse universo.

Menino trabalha mais em cima de difamação. Menina é mais por falsidade. Menino é... Se ele for teu amigo (sinal de ok), mas se tu brigar por qualquer coisa é difamação.

A discrepância de poder evidencia a escola enquanto uma arena de lutas e os estereótipos de gênero também apareceram de forma muito forte no debate. A construção desses papeis, do que é ser menina e do que é ser menino, desde a mais tenra idade, é o que sustenta a estrutura que perpetua a manutenção dessa disparidade de poder e prestígio nesses espaços. Butler (2000) coloca que:

Consideremos a interpelação médica que, apesar da emergência recente das ecografias, transforma uma criança, de um ser "neutro" em um "ele" ou em uma "ela": nessa nomeação, a garota torna-se uma garota, ela é trazida para o domínio da linguagem e do parentesco através da interpelação do gênero. Mas esse tornar-se garota da garota não termina ali; pelo contrário, essa interpelação fundante é reiterada por várias autoridades, e ao longo de vários intervalos de tempo, para reforçar ou contestar esse efeito naturalizado. A nomeação é, ao mesmo tempo, o estabelecimento de uma fronteira e também a inculcação repetida de uma norma (BUTLER, 2000, p. 157).

A norma que a autora coloca aqui é a que rege a vida de todo ser humano mesmo antes dele se entender enquanto tal. Os padrões socialmente estabelecidos que mediam as relações humanas são brutais nesse sentido: preparam uma agenda para que cada um/a seja o que convém à norma.

Revista Tópicos Educacionais, Pernambuco, v. 27, n. 01, p.34-61, 2021. ISSN: 2448-0215. https://periodicos.ufpe.br/revistas/topicoseducacionais/index Dossiê "Conflitos, violências, bullying na escola: problemas da convivência potencializado pela pandemia?" DOI: $10.51359 / 2448-0215.2021 .250294$ 
Soma-se a isso toda uma discrepância estrutural entre gêneros que é tão fortemente consolidada pela cultura patriarcal, o que dificulta qualquer rachadura nesse sistema

Uma das participantes das rodas de diálogo disse que "independente do que você fizer vão te julgar”. A constante iminência de ser sentenciada por qualquer ato faz com que se criem personagens antagonistas: para que haja uma mulher boa é necessário que também exista uma mulher ruim. Esses dois modelos estão imbricados em nosso cotidiano, nas mais diferentes esferas (sobretudo a midiática), moldando as crenças e concepções de todos/as.

Os meninos participam desse universo também sendo ensinados desde muito cedo a se relacionar com esses dois modelos de mulher de maneiras e com finalidades diferentes. A difamação, anteriormente citada como um modus operandi do universo masculino acaba virando um recurso contra todas as mulheres, independentes de consideradas boas ou ruins, visto que este acaba por ser o terreno mais fértil para o surgimento do bullying, tanto partindo dos meninos contra as meninas quantos das meninas entre si.

Durante a realização dessa pesquisa empírica, escutou-se de todas as turmas que falta diálogo, falta apoio por parte da gestão escolar e que o grande problema da escola não é o tempo que passam nela, mas como esse tempo é utilizado. Uma escola que se preocupa com as diferentes formas de aprendizado de seus/suas alunos/as, que oferece disciplinas com conteúdo tão mais próximo de suas realidades, que quebra essa ideia de professor como mestre detentor do conhecimento e reconhece todos os conhecimentos presentes em cada história de cada aluno/a, é uma escola que trabalha o fortalecimento de seus/suas estudantes. Uma escola que enxerga a construção dos saberes como um processo dialógico, entre todas as partes envolvidas, é uma escola que convida seus/suas alunos/as a construir seu "ser político". Uma escola que consegue manter sua autoridade de maneira não opressora é um ambiente que instiga a construção e o desenvolvimento da resiliência em seus/suas estudantes.

Passou-se cerca de três meses mantendo uma troca com os três grupos de meninas, perpassando por assuntos que nem sempre foram fáceis, mas que precisavam desprenderem-se delas. Durante esse tempo assistiu-se à formação de vários processos de autorreflexão, surgimento de dúvidas, questionamentos e, a partir de tudo isso, de florescimento. Perguntadas sobre como se comportavam diante de situações de adversidade, muitas delas mostraram que a semente da resiliência já está plantada, faltando apenas ser regada e cuidada para que cresça saudável.

Revista Tópicos Educacionais, Pernambuco, v. 27, n. 01, p.34-61, 2021. ISSN: 2448-0215. https://periodicos.ufpe.br/revistas/topicoseducacionais/index Dossiê "Conflitos, violências, bullying na escola: problemas da convivência potencializado pela pandemia?" DOI: $10.51359 / 2448-0215.2021 .250294$ 
Revista Tópicos Educacionais

Revista do Programa de Pós-Graduação em Educação

da Universidade Federal de Pernambuco (UFPE)

Dependendo da situação eu posso ficar triste no momento, mas depois ergo a cabeça, penso em novas coisas e continuo minha vida. Tento resolver a situação e se não conseguir, peço ajuda a alguém de confiança.

Procuro seguir em frente de cabeça erguida. A vida é curta pra ficar se culpando, procuro ser mais forte que o fracasso.

Dois tópicos trazidos pelas meninas como sendo pontos fracos da escola, ambiente em que passam a maior parte de seus dias, foram: 1) a falta de um acompanhamento psicológico às discentes e 2) a falta de atividades lúdicas, meditação e demais práticas que ajudem a diminuir o estresse da rotina pesada, mas também como maneira de interagir de outro modo com os professores. Esses pontos que partem delas são elementos que entende-se fazer parte de uma escola que se pretende resiliente.

Fica evidente também que este, como um processo de auto entendimento que pode ser lento e bastante doloroso, deixa marcas profundas que precisam ser ouvidas e trabalhadas de maneira que a capacidade individual de resiliência se sobressaia.

Mesmo que eu tente deixar pra lá, tá me afetando. Ai a gente acaba se retraindo um pouco mais, procurando o erro na gente. A gente sempre pensa que é a gente que tá errando.

Quando um grupo todo se junta pra fazer isso (bullying), você pensa "o erro tá em mim e não em um grupo todo, porque se tá todo mundo se afastando de mim, o problema sou eu”

Entra aqui um elemento que pode ser um grande incentivo na construção e no desenvolvimento do processo de resiliência. O empoderamento também é utilizado como um impulso de mudança, como uma nova maneira de enxergar as situações, especificamente as relações de poder a que estão submetidas. O empoderamento pode ser um processo social e pessoal concomitantemente: ao passo que uma pessoa se empodera de seus traços identitários, ela consegue causar uma movimentação interna em sua autoimagem e, consequentemente, também em sua autoestima.

Revista Tópicos Educacionais, Pernambuco, v. 27, n. 01, p.34-61, 2021. ISSN: 2448-0215. https://periodicos.ufpe.br/revistas/topicoseducacionais/index Dossiê "Conflitos, violências, bullying na escola: problemas da convivência potencializado pela pandemia?" DOI: $10.51359 / 2448-0215.2021 .250294$ 


\section{Revista Tópicos Educacionais}

Quando mulheres negras se perguntam o que tem errado em seus cabelos crespos, quando mulheres gordas se olham no espelho e se sentem verdadeiramente bonitas, quando mulheres lésbicas ou bissexuais percebem que não há problema em se relacionar com outras mulheres, elas estão causando pequenas rupturas num sistema que, por não conseguir entender quem está fora da norma e do padrão socialmente estabelecido como certo/bonito, as trata com violências como o bullying e o cyberbullying.

A gente cresce tendo que seguir um estereótipo. É assim: você tem que ser branca (ou se você for negra tem que alisar o cabelo), você tem que ser magra e você tem que seguir aquilo porque se você não seguir você não vai fazer parte do padrão e você vai ser xingada por causa disso. Eu tive a minha infância todinha querendo alisar o cabelo, por que a maioria das pessoas dizia que cabelo cacheado era 'pixain', era isso e aquilo outro... Antes (...) eu me importava, mas hoje em dia eu tô nem ai, porque eu tenho pra mim que quem tem que se sentir bem sou eu, quem tem que me achar bonita sou eu...(...) Eu que tenho que me sentir bem comigo mesma. Os outros só sabem falar, falar, falar, e ninguém chega (...) pra estender a mão pra você, pra te erguer. (...) Eu acho que primeiro você tem que se olhar no espelho e dizer 'pô, eu sou um mulherão da porr*' Por que realmente a gente é bonita, a gente não tem que se preocupar com que os outros vão falar não.

Meninas empoderadas dificilmente serão alvo de bullying, porque quando o autor tentar atingi-las, elas estarão bastante conscientes de si, de suas características, de suas particularidades e não vão enxergá-las como um ponto fraco. É a partir dessa consciência que também se constrói uma base resiliente, onde a superação das adversidades estará amparada.

\section{CONCLUSÃO}

Os dados que foram coletados na pesquisa empírica e aqui apresentados mostraram-se alinhados à bibliografia (FANTE, 2005, BANDEIRA; HUTZ, 2012) previamente consultada, referente à temática do bullying. Conseguiu-se confirmar que uma alta porcentagem de meninas se identifica enquanto alvo de bullying, este ocorrido no passado ou no tempo corrente, pois ele

Revista Tópicos Educacionais, Pernambuco, v. 27, n. 01, p.34-61, 2021. ISSN: 2448-0215. https://periodicos.ufpe.br/revistas/topicoseducacionais/index Dossiê "Conflitos, violências, bullying na escola: problemas da convivência potencializado pela pandemia?" DOI: $10.51359 / 2448-0215.2021 .250294$ 
acontece em qualquer escola de qualquer parte do mundo, tendo a grande maioria dificuldades de procurar ajuda em outras instâncias, como família ou gestão escolar.

Ainda que receba atenção de pesquisadores e demais profissionais da educação, a escola continua pouco discutida com seus/suas principais sujeitos/as: os/as alunos/as. Discutir o conceito de escola, seu espaço, sua serventia, metodologia e uma possível e primordial atualização são essenciais para que a educação cumpra seu papel emancipador e não continue com uma formação passiva e acrítica, com um tom demagógico que em nada serve o jovem do século XXI.

Esse espaço, configurado como o que temos hoje, acaba por ser terreno fértil para que a agressividade inerente ao ser humano seja erroneamente expressada das mais variadas formas, dando origem a um leque de violências diárias, sendo o bullying apenas uma delas. Uma prática tão comum, em algumas ocasiões bastante sutil, o que inclusive dificulta sua identificação, mas que causa danos por vezes irreparáveis a quem o sofre.

O bullying cometido contra meninas tem características bem peculiares que exige um olhar mais apurado e uma maior atenção à suas nuances. Se bullying é também uma demonstração de poder, pelas mais variadas razões, é necessário entender como as meninas agem nesse processo. Houve aqui a oportunidade de provocar as meninas participantes a questionar seus papeis em suas relações com outras meninas, se eram simultaneamente alvo e autoras e a partir desse exercício de autorreflexão pensar em como melhorar o clima escolar, tão calejado por essas violências diárias.

Pode-se inferir, através das trocas com as participantes, que promover um ambiente saudável para o fortalecimento e empoderamento das meninas é essencial para a construção de uma segurança a respeitos de traços identitários que as levam a sofrer o bullying em primeira instancia. A partir disso, conseguem reagir à violência que é voltada contra elas e com um cenário mais ameno tendem a se tornar resilientes sobre todo o processo.

Entende-se aqui que essas duas palavras-chave, empoderamento e resiliência, podem ser lidos como elementos impulsores e um campo de possibilidades para a discussão do bullying por uma ótica centrada na resolução de conflitos. Considera-se também o fortalecimento de vínculos entre o eixo família-jovem-escola como um caminho possível para problematizar a questão, fazer esse/a jovem ser escutado/a e diminuir a incidência de autores e, consequentemente, de alvos.

\section{REFERÊNCIAS BIBLIOGRÁFICAS}

Revista Tópicos Educacionais, Pernambuco, v. 27, n. 01, p.34-61, 2021. ISSN: 2448-0215. https://periodicos.ufpe.br/revistas/topicoseducacionais/index Dossiê "Conflitos, violências, bullying na escola: problemas da convivência potencializado pela pandemia?" DOI: 10.51359/2448-0215.2021.250294 
ARANTES, Valéria Amorim. Afetividade e Cognição: Rompendo a dicotomia na educação. In:\ OLIVEIRA, Maria Kohl ; TRENTO, Denise; REGO, Teresa (org). Psicologia, Educação e as temáticas da vida contemporânea. São Paulo: Moderna, 2002. Disponível em: http:/hottopos.com/videtur23/valeria.htm

BANDEIRA, Cláudia de Moraes. Bullying: Auto-estima e diferenças de gênero. Dissertação (Mestrado em Psicologia) - Programa de Pós-Graduação em Psicologia do Desenvolvimento, Universidade Federal do Rio Grande do Sul. Porto Alegre, 2009.

BANDEIRA, Cláudia de Moraes; HUTZ, Cláudio Simon. Bullying: prevalência, implicações e diferenças entre os gêneros. Revista Semestral da Associação Brasileira de Psicologia Escolar e Educacional, São Paulo. Volume 16, Número 1, p. 35-44 Janeiro/Junho. 2012.

BUTLER, Judith. Corpos que pesam: sobre os limites discursivos do "sexo". In: LOURO, Guacira Lopes. O corpo educado: pedagogias da sexualidade. Belo Horizonte: Editora Autentica, 2000, p. 151-172.

CORTEZ, Miriam Béccheri; SOUZA, Lídio de. Mulheres (in)Subordinadas: o Empoderamento Feminino e suas Repercussões nas Ocorrências de Violência Conjugal. Psicologia: Teoria e Pesquisa, Brasília. Vol. 24, n. 2, p. 171-180, Abril/Junho. 2008.

CYRULNIK, Boris. Os patinhos feios. São Paulo: Martins Fontes. 2004.

FAJARDO, Indinalva Nepomuceno; MINAYO, Maria Cecília de Souza; MOREIRA, Carlos Otávio Fiúza. Educação escolar e resiliência: política de educação e a prática docente em meios adversos. Ensaio: Avaliação e Políticas Públicas em Educação, Rio de Janeiro, v. 18, n. 69, p. 761-774, out./dez. 2010.

FANTE, Cléo. Fenômeno Bullying: como prevenir a violência nas escolas e educar para a paz. Campinas: Versus, 2005.

FANTE, Cléo; PEDRA, José Augusto. Bullying escolar: perguntas e respostas. Porto Alegre: Artmed, 2008.

FERREIRA, Hugo Monteiro. As abordagens disciplinar e transdisciplinar e as práticas pedagógicas. In:\ FERREIRA, Hugo Monteiro (Org.). A Educação Integral e a Transdisciplinaridade. Recife: Gráfica \& Editora (Coleção RENAFORM - UFRPE), 2016.

FOUCAULT, Michel. O Sujeito e o Poder. In: RABINOV, Paul; DREYFUS, Hubert. Michel Foucault: uma trajetória filosófica - para além do estruturalismo e da hermenêutica. Tradução: Vera Porto Carrero. Rio de Janeiro: Forense Universitária, 1995, p.229-249.

FOUCAULT, Michel. Vigiar e Punir. Tradução: Raquel Ramalhete. Petrópolis: Vozes, 1987

GARCIA, Dantielli Assumpção; SOUSA, Lucília Maria Abrahão. A sororidade no ciberespaço: laços feministas em militância. Estudos linguísticos, São Paulo, vol. 44, n.3; p.991-1008, set. dez, 2015

Revista Tópicos Educacionais, Pernambuco, v. 27, n. 01, p.34-61, 2021. ISSN: 2448-0215. https://periodicos.ufpe.br/revistas/topicoseducacionais/index Dossiê "Conflitos, violências, bullying na escola: problemas da convivência potencializado pela pandemia?" DOI: $10.51359 / 2448-0215.2021 .250294$ 
HOOKS, Bell. Feminism is for everybody: passionate politics. Cambridge, MA, 2000.

HOROCHOVSKI, Rodrigo Rossi; MEIRELLES, Giselle. Problematizando o conceito de Empoderamento. Anais do II Seminário Nacional Movimentos Sociais, Participação e Democracia. Núcleo de Pesquisa em Movimentos Sociais - NPMS. Universidade Federal de Santa Catarina, Florianópolis. Abril, 2007.

LARROSA, Susana Rocca. Resiliência: um novo paradigma que desafia a reflexão e a prática pastoral. Revista Atualidade Teológica, Rio de Janeiro, Pontifica Universidade Católica, n.28, jan-abril 2008. Disponível em: < http://www.maxwell.vrac.puc-rio.br/18361/18361.PDFXXvmi=>

LEON, Oscar Dávila. Adolescência e juventude: das noções às abordagens. In:\FREITAS, Maria Virgínia de (Org.). Juventude e adolescência no Brasil: referências conceituais. São Paulo: Ação Educativa, 2005. p. 9-18.

LOURO, Guacira Lopes. Pedagogias da sexualidade. In: LOURO, Guacira Lopes (Org.) O corpo educado: pedagogias da sexualidade. Belo Horizonte: Editora Autentica, 2000. p. 4-24

MALDONADO, M. T. Bullying e cyberbullying: o que fazemos como o que fazem conosco? Ed. 01. São Paulo: Moderna, 2011.

MENEGOTTO, Lisiane Machado de Oliveira; PASINI, Audri Inês.; LEVANDOWSKI, Gabriel. O bullying escolar no Brasil: uma revisão de artigos científicos. Revista Psicologia: teoria e prática, São Paulo, v. 15, n. 2, p. 203-215, maio/ago. 2013.

NASCIMENTO, Maria Anezilany Gomes do; SILVA, Cícero Nilton Moreira da. Rodas de Conversa e Oficinas Temáticas: experiências metodológicas de ensino-aprendizagem em Geografia. $10^{\circ}$ Encontro Nacional de Prática de Ensino em Geografia, Porto Alegre, Agosto, 2009.

OLWEUS, Dan. Bully/victim problems in school: Facts and intervention. European Journal of Psychology of Education, Vol. XII, ltD 4,495-510 e. 1997.

PELTZ, Lidiane; MORAES, Maria da Graça; CARLOTTO, Mary Sandra. Resiliência em estudantes do ensino médio. Psicologia Escolar Educacional, Campinas, vol.14, n.1, pp.87-94. 2010 .

PENKALA, Ana Paula. A mulher é o novo preto: pensando identidades a partir das representações arquetípicas de gênero na série Orange is the new black. Revista Paralelo 31, Pelotas. Ed. 3, p. 212-229, Dez 2014.

PESCE, Renata; ASSIS, Simone; SANTOS, Nilton; OLIVEIRA, Raquel Carvalhaes de Oliveira. Risco e Proteção: Em Busca de Um Equilíbrio Promotor de Resiliência. Psicologia: Teoria e Pesquisa, Brasília, Vol. 20, n. 2, p. 135-143. Mai-Ago de 2004.

SILVA, Ana Beatriz Barbosa. Bullying: Mentes perigosas nas escolas. Rio de Janeiro: Objetiva, 2010.

Revista Tópicos Educacionais, Pernambuco, v. 27, n. 01, p.34-61, 2021. ISSN: 2448-0215. https://periodicos.ufpe.br/revistas/topicoseducacionais/index

Dossiê "Conflitos, violências, bullying na escola: problemas da convivência potencializado pela pandemia?" DOI: $10.51359 / 2448-0215.2021 .250294$ 
Revista Tópicos Educacionais

Revista do Programa de Pós-Graduação em Educação

da Universidade Federal de Pernambuco (UFPE)

SOUSA, Carolina; MIRANDA, Francisco; NIETO, Mari Carmem Lara; DORES, Ricardo. Educação para resiliência. Revista Conhecimento \& Diversidade, Niterói, Vol. 6, n. 11, p. 2640. Jan./Jun. 2014.

TAVARES, José. A resiliência na sociedade emergente. In: TAVARES, José (org). Resiliência e educação. São Paulo: Cortez Editora. 2001. P. 43-75.

Recebido em abril de 2021.

Aprovado em junho de 2021.

Revista Tópicos Educacionais, Pernambuco, v. 27, n. 01, p.34-61, 2021. ISSN: 2448-0215.

https://periodicos.ufpe.br/revistas/topicoseducacionais/index

Dossiê "Conflitos, violências, bullying na escola: problemas da convivência potencializado pela pandemia?" DOI: $10.51359 / 2448-0215.2021 .250294$ 